\title{
Arsenic Remediation by Synthetic and Natural Adsorbents
}

\author{
Muhammad Saqaf Jagirani ${ }^{1}$, Aamna Balouch*1, ${ }^{1}$ dbdullah $^{1}$, Ali Muhammad \\ Mahar ${ }^{1}$, Faraz Ahmed Mustafai ${ }^{1}$, Kausar Rajar ${ }^{1}$, Aqsa Tunio ${ }^{1}$, \\ Saman Sabir ${ }^{1}$ and Muhammad Kashif Samoon ${ }^{2}$ \\ ${ }^{1}$ National Centre of Excellence in Analytical Chemistry, University of Sindh, Jamshoro, 76080, Pakistan \\ ${ }^{2}$ Centre for pure and Applied Geology, University of Sindh, Jamshoro, 76080, Pakistan \\ *Corresponding Author Email: aamna_ablouch@yahoo.com \\ Received 24 May 2017, Revised 22 June 2017, Accepted 23 June 2017
}

\begin{abstract}
The contagion of toxic metals in water is a serious environmental and health concern and threatening problem worldwide. Particularly arsenic contamination in ground water has became great dilemma in the earlier decades. With advent in research for arsenic remediation, standard of drinking water is improving and now reduced to few parts per million (ppm) level of arsenic in drinking water sources. However, due to continuous enhancement in environmental pollution, remediation techniques are still needed to achieve the drinking water quality standard. Development of novel and economically feasible removal techniques or materials for selective separation of this toxic specie has been the main focus of research. Several arsenic removal techniques, including membrane separation, coagulation, precipitation, anion exchange have been developed. The aim of this article is to review briefly arsenic chemistry and previous and current available technologies that have been reported various low-cost adsorbents for arsenic removal.
\end{abstract}

Keywords: Arsenic removal, Metal toxicity, Water purification, Removal techniques, Low cost adsorbents

\section{Introduction}

Metals toxicity is serious health concern due to their chronic and acute toxicity, specifically heavy metals have tendency to aggravate the different cancers. Among heavy metals arsenic (As) is naturally occurring hazardous element found at trace levels in air, water, soil, and food [1-6]. The elevated level of arsenic in ground water increase due to the anthropological activities as well as natural phenomena has posed serious health issues [7-9]. As exposure in food and water poses serious health effects in humans, it may cause non-cancer effects (hyper- and hypo-pigmentation, keratos is, black foot disease, hypertension, cardiovascular diseases and diabetes), and/or carcinogenic such as typical skin, lung and bladder cancers [1, 3, 4, 1017]. According to the World Health Organization (WHO) classification, arsenic has been label as a first group carcinogenic substance [18]. However, arsenic has been recognized as one of the most noxious element as extensive but just its cumulative role as a toxin of water has expanded attention of scientists throughout the world. It is because of their increasing concentration in water through geothermal dissolution of reserves and mineral ores [19]. Mining of coal or other rocks, fossil fuel burning and casting of non-iron metals has been found the main industrial methods that contribute to anthropogenic As impurities in water [20]. Study showed that about $70 \%$ of Arsenic production is due to copper chrome arsenate (CCA) used timber treatment where as $22 \%$ is produced in agricultural chemicals other may be in glass, non-ferrous alloys and pharmaceuticals [21]. The oxidation state and toxicity of arsenic varies 
from organic or inorganic in the terminology of the oxidation state. Arsenic occurs in four forms which are arsenic (0), arsenite As(III), arsine As(III) and arsenate As (V).Among these four oxidation states the inorganic arsenite and arsenate is commonly found in the water, these are the most prevalent forms of the arsenic [22]. Due to the slow transformation of the redox, arsenite and arsenate both are oxidized and reduced in the environment [23]. Under the anoxic reduction reaction (e.g., reduced sediments, subsurface waters) mostly arsenic occurs as arsenite, however the arsenate is prevalent in aerobic oxidation condition such as surface water [24]. The $\mathrm{pH}$ plays a key role while determining the state of arsenic, the solubility of arsenic is very low at neutral or slightly acidic conditions, but it may increase drastically both at very low $\mathrm{pH}$ (below 2.0) and at very high $\mathrm{pH}$ (above 9.0). 2. The maximal amounts of arsenic that might be released from soils in extremely acidic $(\mathrm{pH}<2)$ or extremely alkaline $(\mathrm{pH}>9)$ conditions depend on the total arsenic concentration. [25-28]. The As(III) is about more than 60 times toxic then $\mathrm{As}(\mathrm{V})$, it may be due to higher cellular uptake $[22,29.30]$. Due to its toxicity about 130 million people in 2001were affected and a considerable increase was observed in the number of people affected by arsenic [31]. Hence the high and worst contamination of arsenic in ground water is observed and reported in Asian countries, mainly in India, Pakistan, Bangladesh and West Bengal, [32-34]. It has been reported that about 60-100 million people in India and Bangladesh are currently at risk, due to arseniccontaminated drinking waters [6, 31, 35, 36]. In these both areas the drinking resources to the population are water supply and tube-wells and 79.9 million and 42.7 million natives are using the contaminated water which has arsenic concentrations above then $50 \mu \mathrm{g} / \mathrm{L}$ [37, 38]. Likewise, the concentration of arsenic in the underground water of some area is as high as 4730 $\mu \mathrm{g} / \mathrm{L}$ [39]. According to the WHO and US-EPA, the maximum concentration of arsenic is allowed in drinking water is $10 \mu \mathrm{g} / \mathrm{L}$ [40]. But for different countries the permissible limit is vary due to high arsenic contaminated waters, listed in Table 1. For the past three decades, a number of studies showed that arsenic- contaminated water is one of the principle threats for the human health
[41, 42]. Arsenic enters in the human body from different sources like, digestion, breathing and skin absorption. It is distributed in different large number of living organs like liver, lungs, kidney and skin [43]. Erythrocyte contain about 95 - $99 \%$ of arsenic which is bound to hemoglobin and it is transported to all body parts. It is reported that about $70 \%$ arsenic level is excreted through urine. The form of Arsenic which is excreted in urine is mainly in methylated form which is less toxic. The levels of arsenic appears in skin are counted lower as compared to other organs [44, 45]. Different studies have been taken in different times regarding the fate of arsenic in environment and its behavior in several pollution as hazardous substance [30, 40, 44]. Chronic exposure of inorganic arsenic in concentrations above $50 \mu \mathrm{g} / \mathrm{L}$ in drinking water, can cause diverse skin lesion such as hyper pigmentation, hyperkeratosis and cancers including skin, lung, kidney, bladder, the disease cause by arsenic termed as arsenicosis [30].

Table.1. Countries affected by arsenic contamination and WHO permissible limits for drinking water.

\begin{tabular}{llcc}
\hline S. No & Country Name & WHO Limit in $(\boldsymbol{\mu g} / / \mathbf{L})$ & References \\
\hline 1 & Argentina & 50 & {$[46-48]$} \\
2 & Bangladesh & 50 & {$[49,50]$} \\
3 & Cambodia & 50 & {$[51]$} \\
4 & China & 50 & {$[52,53]$} \\
5 & Chile & 50 & {$[54-57]$} \\
6 & India & 10 & {$[58]$} \\
7 & Japan & 10 & {$[59]$} \\
8 & Mexico & 50 & {$[60,61]$} \\
9 & Nepal & 50 & {$[62]$} \\
10 & New Zealand & 10 & {$[63,64]$} \\
11 & Pakistan & 10 & {$[65-67]$} \\
12 & Taiwan & 10 & {$[52,53]$} \\
13 & USA & 10 & {$[68,69]$} \\
14 & Vietnam & 10 & {$[70-71]$} \\
\hline
\end{tabular}

\section{Conventional Techniques}

Several techniques are available for the removal of arsenic from contaminated water like as oxidation- precipitation [100-106], adsorption [107], coagulation-flocculation filtration [108], ion exchange and membrane filtration like reverse osmosis [109] and nanofiltration [110]. Each of the above technique has its own advantages and disadvantages it make very difficult to choice an appropriate method. There are many drawback of conventional techniques such as cost (oxidation, coagulation-flocculation-filtration and nanofiltration), high slurry production (electrochemical 
treatment, coagulation-flocculation), membrane fouling (nanofiltration), and continuous monitoring of the ion concentration (ion exchange) [111].

\section{Adsorption Method}

The adsorption is known as one of the popular method used to eliminate arsenic from aqueous solution. Adsorption method is said as most economic and efficient method for the treatment of water and process is similar to ionexchange. The cost of process depends upon the cost of adsorbent [40]. Some known adsorbents used for the removal of arsenic are hydrous titanium dioxide $\left(\mathrm{TiO}_{2}\right)$ [112, 113], various iron oxides/hydroxides [114], synthetic zeolites [115, 116], activated carbon [117], and activated alumina [118]. For the removal of arsenic different biological origins, wastes and industrial by products are also used [112]. Due to toxic nature of arsenic scientists are seriously working for the development of new adsorbent methods which must be more rapid and cost effective than reported methods [115]. The development of nano-size adsorbents are taking great concentration in this regard due to their high surface area and high tendency to adsorb arsenic from water. Synthesis of nano particles have been employed from respective metal and metal oxides e.g. gold, titanium oxide, cupric oxide, metal oxide nanomaterials, nano-iron, impregnated granulated activated carbon, synthetic nanostructured $\mathrm{Fe}(\mathrm{III})-$ $\mathrm{Cr}$ (III) mixed oxides [119-123]. For the removal of arsenic few papers $h$ arsenic been reported. The cupric oxide nanoparticles have been used as adsorbent for the removal of As(III) and (V). These researchers have studied the different parameters such as $\mathrm{pH}$ effect, equilibrium behavior, temperature, and turbulence [124]. They have used the Langmuir and Freundlich isotherm model to check the equilibrium behavior of the system, the main advantage of this technique is the reuse of adsorbent material. It is reported that this method is highly $\mathrm{pH}$ dependent so effect of different species may alter the require $\mathrm{pH}$. This is time consuming method takes about $1 \mathrm{~g} / \mathrm{L}$ adsorb in 5 hours. The efficiency of adsorbent decreases in time intervals and the presence of different ions such as sulfate and phosphate ions reduces adsorbent efficiency by 10 to $20 \%$, respectively [120].

\section{Natural adsorbents}

Different cost effective adsorbents have been used for the removal of arsenic such as iron oxide coated fungal biomass [125], methylated yeast biomass [126], modified fungal biomass, residue rice polish [127], acid-washed crab shells [128], modified fungal biomass [129,130], modified coconut coir pith [131], modified cotton cellulose [132], bone char [133], shrimp shells [134], saw dust of spruce (Picea abies) that is chemically modified [135], HDTMA modified zeolite [136], iron-coated zeolite [137] and surfactant-modified zeolite [138]. Different chemically or physically modified materials are used but their performance was found to be poor towards lower concentrations.

\section{Waste of pomegranate fruit}

The waste of pomegranate fruit as a bioadsorbent has been used for decontamination of As(III) in water. Bio-adsorbent was prepared by acid treatment and loaded with $\mathrm{Fe}$ (III) to check the adsorption efficiency for the As [139]. Many factors including $\mathrm{pH}$, initial arsenic level, adsorbent dose and contact time on adsorption of As(III) onto Fe-CPW were examined. The optimum $\mathrm{pH} 9$ was best suited for $70.7 \%$ removal of $\mathrm{As}(\mathrm{III})$ at 2 hours equilibrium time for the adsorption of $\mathrm{As}(\mathrm{III})$ onto Fe-CPW. The main advantage of this method is low cost bio adsorbent prepared from pomegranate waste has been investigated for the removal of As(III) from water [139]. However, the adsorption of As(III) was found to be strongly dependent upon $\mathrm{pH}$ of the solution and it takes longer time during experiment [139].

\section{Orange peel}

Orange peel is used as bio absorbent to reduce the concentration of arsenic below the standard level form the aqueous media. Orange peel is used without any chemical modification for the removal of arsenic from real samples [140]. However, this method is laborious and time 
consuming. According to literature survey this method is selective at particular $\mathrm{pH}$ and shaking speed is also selective for the desired adsorbent capacity $[138,140]$.

\section{Raw rice husk}

Rice husk is an agro waste and abundantly available at low cost. The potential of rice husks as an adsorbent has been used for the removal of $\mathrm{As}(\mathrm{V})$ from groundwater [141]. Rice husk is considered as low cost agro waste. Furthermore, various factors including, adsorbent dose flow rate, particle size of adsorbent, metal concentration and column diameter for the maximum removal of arsenic was explored to investigate the potential of raw rice husk as adsorbent as well as performance of fixed bed column [142], the reported method rely on the surface of column, $\mathrm{pH}$ specific for the As(V).

\section{Tea waste}

The tea waste, straw and microbial biomass have been used generally as an inexpensive adsorbent [143-152]. Earlier reported that tea waste is more capable to trap the metals owing its insoluble cell and highly porous structure [153-157]. The present functional groups in tea waste also enhanced trapping action. Therefore the adsorption capacity of As are investigated extensively in comparison to recommend an inexpensive alternative to activated carbon. This method is time consuming and it is also reagent dependent [158].

\section{Bone char}

Bone char is derived from the crushed animal bones through the carbonization by heating over $500-700{ }^{\circ} \mathrm{C}$ in iron retort in the absence of air for 4-6 h. The composition of bone charcoal is calcium carbonate (7-9 wt\%), carbon content (9$11 \mathrm{wt} \%)$ and calcium hydroxylapatite (CaHAP) (70-76 wt\%) etc. The bone char is used for the removal of $\mathrm{As}(\mathrm{V})$ has been done as a function of $\mathrm{pH}$, contact time and dosage of adsorbent [159]. The kinetics study resulted that the adsorbent of $\mathrm{As}(\mathrm{V})$ was rapid in the first $30 \mathrm{~min}$ however equilibrium time was not dependent of initial
As $(\mathrm{V})$ concentration. According to Fourier transform infrared (FTIR) spectra of bone char the $\mathrm{Ca}-\mathrm{OH}$ functional group plays a key role for the adsorption of $\mathrm{As}(\mathrm{V})$ ion before and after adsorption. The mechanisms of the $\mathrm{As}(\mathrm{V})$ adsorption on bone char was complex where both ion exchange and co-precipitation mechanisms were fallowed. The arsenic removal was strongly dependent on $\mathrm{pH}$ and dosage of adsorbent this method is only applicable for the adsorption of $\mathrm{As}(\mathrm{V})$ ion [160].

\section{Banana Peel}

The waste of plant material is alternative to chemical method for the sorption of metal ions $[161,162]$. There are number of reported methods for the removal of arsenic which are either costly or not easily available in Pakistan [163]. However, the banana peel has been used owing its low cost and easily available in our area. The banana peel was used for the adsorption of arsenic species from the ground water. The adsorption of arsenic species on banana peel was observed $\mathrm{pH}$ independent. Besides the advantages of this method its process gets slower with passage of time [164].

\section{Acid-washed crab shells (AWCS)}

During the last few years the advanced knowledge of biosorption relatively low costs, high adsorption capacities and regenerability of natural bio adsorbent materials $[165,166]$. Some of them have the efficient capacities for the removal of arsenate as a biosorption [167,168]. However different challenges rising biosorbents with low cost and high uptake as well as sympathetic the bio adsorbent mechanism still remain. Current results proved that acid-washed crab shells (AWCS) have a capably for binding anionic metal species such as chromate cyanide, gold and vanadate [169]. Fourier transform infrared analysis (FTIR) is used for the study of the biosorption mechanism of arsenate. This method is strongly $\mathrm{pH}$ dependent and time consuming process [170].

\section{Synthetic adsorbents Surfactant-modified zeolite}

Natural zeolites are synthesized from amino-silicate materials which are effective for the 
exchange of cations [171], but having low capability towards anions, such as Arsenite. Unmodified clinoptilolite is a type of natural zeolite the which has also been reported and show the adsorption capacity up to $1.5 \mu \mathrm{g} / \mathrm{g}^{-1}$ at equilibrium time was attain at $60 \mathrm{~min}$ as compare to modified clinoptilolite it is very low capacity of adsorption it is time consuming process [172].

The hexadecyltrimethyl ammonium bromide (HDTMA) adsorbent materials are used as the surfactant for the modification of fly ash based commercial zeolites [173-175]. These are called surfactant-modified zeolite (SMZ) adsorbents. The SMZ forms active sites for anions adsorption due to the presence of amino group [176]. This modification of natural zeolite has enhanced the capability of arsenite removal due to its chemical as well as surface charge modification. The SMZ is an adsorbent used for the removal of arsenate from aqueous media. Many researchers have reported that sulfate, selenite and hydrogen chromate is used for the adsorption of anion on SMZ $[174,177,178]$. The absorption of polyhexamethylene guanidine-chloride on zeolite for the removal of As (V) using SMZ. According to him the adsorption capacity was about $6 \mathrm{mg} / \mathrm{g}$ at a concentration of $1000 \mathrm{mg} / \mathrm{L}$ at equilibrium. The drawback of this method was that the effect of $\mathrm{pH}$ and temperature on adsorbing capacity has not been investigated systematically. This method only attributed to aqueous solutions and favors on specific temperature [179].

\section{Iron containing high surface area compounds}

The iron containing (Iron Oxides) are known efficient adsorbing material due to their economic value, efficiency and strong affinity for the removal of As [180]. The reported method was modified for the preparation of magnetite (an iron ore) [181], that has increased the adsorption capabilities of As(III \& V) to 2237 and 26 times respectively $[182,183]$. The addition of $\mathrm{FeCl}_{3}$ supplementary to raw material used in conventional method formed the amorphous structure and enhanced the surface area of compound. The dispersion of hydrated iron oxide particles which behave as colloidal solution in addition with Amberlite XAD-2 resin (macro porous ion exchange resins) activate the hybrid sorbent material and gives efficiency up to $90 \%$ removal of $\mathrm{As}(\mathrm{V})$ [184]. It was proved that iron oxide such as zero valent iron particles (modified and unmodified) are considered as pretty useful adsorbents [185-188]. The goethite nanoparticles $(\alpha-\mathrm{FeOOH})$ synthesized from hydrazine sulfate through a wet-chemical method is known as good adsorbent for arsenic. This study suggested that the dose of $6 \mathrm{~g} / \mathrm{L} \alpha-\mathrm{FeOOH}$ adsorbent is enough for the elimination of As (V) upto $99 \%$ from water with $50 \mathrm{mg} / \mathrm{L}$ concentration of As (V) [188]. The mesoporous lepidocrocites $(\gamma-\mathrm{FeOOH})$ heat treated adsorbent showed 94\% removal efficiency for As (III) and $>99 \%$ for $\mathrm{As}(\mathrm{V})$ as reported [189]. The ultrafine $\alpha-\mathrm{Fe}_{2} \mathrm{O}_{3}$ nanoparticles are more efficient than $\gamma$-FeOOH because of their smaller size and high surface area, they are more capable for removal of As (III) from the aqueous media [190]. Besides these advantages, there are some drawbacks of iron oxides due to powdery form it is difficult to separate from treated water. So researchers are working on the modification of iron compounds in the regard of economic value and adsorbent capacity.

\section{Magnetite}

The magnetite is a form of iron oxide which is remarkable functional material in different fields like magnetic, catalyst, adsorption, and separation. It is efficient adsorbent for $\mathrm{As}$ (III) and As(V) [19], 192], nowadays magnetites are developed by precipitation solvothermal and solgel hydrothermal methods [192,193]. Among these the precipitation method is preferred due to simple operation and cheap material. Conditions for this method can be set at desired purposes. The main drawback of this method is that the solution of magnetite can only be prepared in low dielectric solvent and/or aqueous [194].

\section{Non-ferrous compounds and nano-clusters}

The inorganic nanoparticles are 5 to 10 times more efficient then micro size particles due to their chemical characteristics, high surface to mass ratio, and surface reactivity [195]. Most recent studies showed that the aluminum nanoclusters are widely used for such applications 
[196], it has been reported that the main constituent in the coagulant polyaluminium chloride (PACL) is aluminum nanoclusters which is used for the remediation of water. The aluminum nanoparticles have specific surface charge and contain large number of $\mathrm{OH}$ group due to their ability to deprotonate over a wide $\mathrm{pH}$ range. For the increase in adsorption efficiency PACL is added to arsenic contaminated water in granulated or powdery form in conventional method. This method relies at specific $\mathrm{pH}$ range. Co- precipitates with $\mathrm{Al}$ flocks above $\mathrm{pH} 7$ lowers the efficiency for the adsorption of As(III) [196].

After complete review we have compile all the adsorbent reported for arsenic removal and their adsorption capacity in tabulated and graphical form. Table 2 and 3 represents the different adsorbents reported in literature for $\mathrm{As}(\mathrm{V})$ and As(III). The bar graphs showed in figure 1 and 2 represents the adsorption capacity of all adsorbents which are mention in Table 2 and 3 respectively.

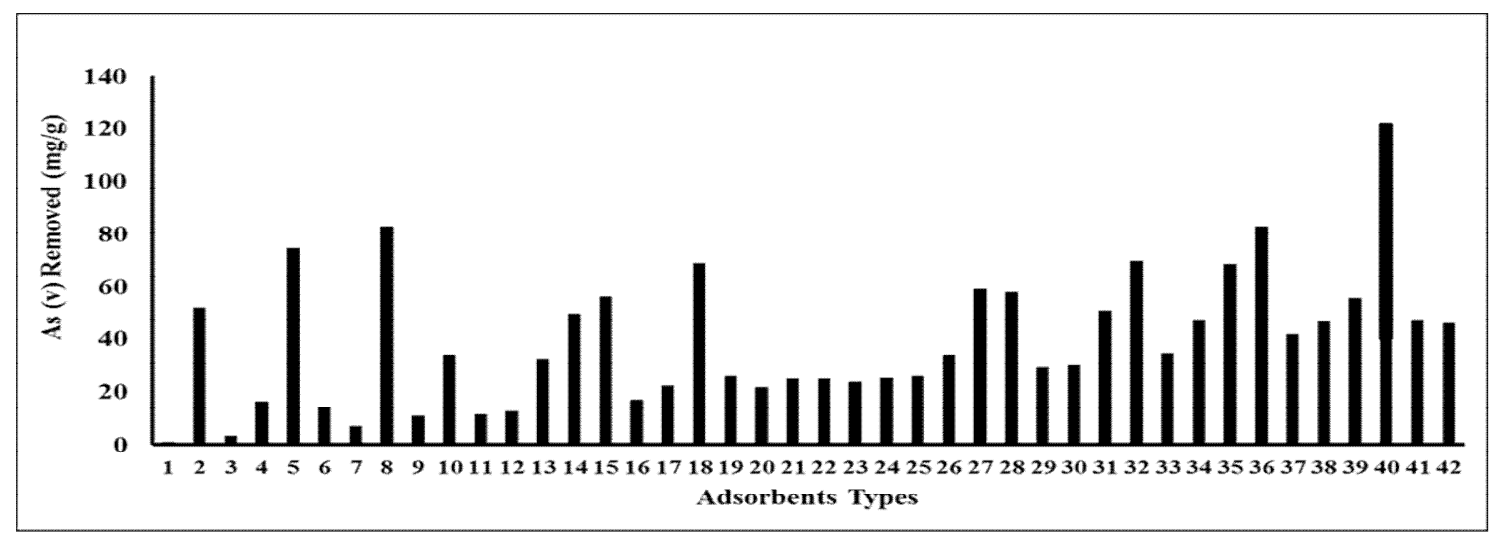

Figure 1. Adsorption capacity of different adsorbents reported for arsenic (V)

Table 2. Comparative evaluation among different adsorbents for Arsenic (V).

\begin{tabular}{|c|c|c|c|c|}
\hline S.No & Adsorbents & pH & Type of water & References \\
\hline 1 & Rice husk & 8.00 & Groundwater & {$[72,127,142]$} \\
\hline 2 & Orange Peel & 7.00 & Drinking water & {$[139$} \\
\hline 3 & Bone char & 10.00 & Aqueous media & [73] \\
\hline 4 & Tea waste & 5.00 & Drinking water & [74] \\
\hline 5 & Banana Peel & - & Groundwater & [164] \\
\hline 6 & Acid-washed crab shells & 3.55 & Aqueous solution & {$[19]$} \\
\hline 7 & Rice Polish & 4.00 & Aqueous solution & [21] \\
\hline 8 & Coconut-shell carbon & 5.00 & Drinking water & {$[75]$} \\
\hline 9 & Sorghum biomass & 5.00 & Groundwater & {$[76,77]$} \\
\hline 10 & Eggshell membrane & 7.00 & Groundwater & {$[78,79]$} \\
\hline 11 & Natural siderite & 7.31 & Tap water & {$[80]$} \\
\hline 12 & Activated red mud & 3.50 & Distilled water & {$[81]$} \\
\hline 13 & Bamboo charcoal & $3-4$ & Aqueous solution & {$[82]$} \\
\hline 14 & Synthetic zeolite H-MFI-24 & 6.5 & Distilled water & {$[115]$} \\
\hline 15 & Granular titanium dioxide & 7.00 & Ground Water & {$[83]$} \\
\hline 16 & Granular ferric hydroxide (GFH) & 6.5 & Distilled water & {$[114]$} \\
\hline 17 & Iron-oxide-coated manganese sand (IOCMS) & 7.00 & Distilled water & {$[84]$} \\
\hline 18 & Iron-modified activated carbon & 8.0 & Distilled water & {$[85]$} \\
\hline 19 & Amorphous iron hydroxide & 6.00 & Distilled water & {$[86]$} \\
\hline
\end{tabular}


Pak. J. Anal. Environ. Chem. Vol. 18, No. 1 (2017)

\begin{tabular}{|c|c|c|c|c|}
\hline 20 & Zero-valent iron & 10.00 & Groundwater & [87] \\
\hline 21 & Goethite & 6.00 & Distilled water & [86] \\
\hline 22 & Ti xHy-Montmorillonite & 8.00 & Distilled water & [86] \\
\hline 23 & Kaolinite & 7.31 & Tap water & [88] \\
\hline 24 & Modified calcined bauxite & 7.00 & Distilled water & [89] \\
\hline 25 & Cerium-loaded cation exchange resin & 5.00 & Distilled water & [90] \\
\hline 26 & Surface-modified diatomite & 7.00 & Artificial wastewater & [7] \\
\hline 27 & Granular titanium dioxide $\left(\mathrm{TiO}_{2}\right)$ & 7.00 & Ground water & [83] \\
\hline 28 & Pillared Clays and Iron Oxides & 10.00 & Drinking water & [86] \\
\hline 29 & SMZ & 7.00 & Aqueous solution & [91] \\
\hline 30 & Magnetite & 7.00 & Distill water & [183] \\
\hline 31 & Iron modified bamboo & $3.00-4.00$ & Drinking Water & [109] \\
\hline 32 & Lepidocrocites & 3.00 & Aqueous solution & [92] \\
\hline 33 & $\mathrm{Cu}(\mathrm{II})$ oxides & 8.00 & Drinking water & [189] \\
\hline 34 & PEG-MWCNTs & 4.00 & Drinking water & [93] \\
\hline 35 & (Ti-BYC) & 7.00 & Aqueous solution & [94] \\
\hline 36 & $\alpha-\mathrm{Fe}_{2} \mathrm{O}_{3}$ nanoparticles & 7.00 & Tap water & [95] \\
\hline 37 & $\mathrm{Fe}_{2} \mathrm{O}_{3}$ nanoparticles & 6.00 & Drinking water & [96] \\
\hline 38 & Magnetite nanoparticles & 6.50 & Aqueous solution & [97] \\
\hline 39 & $\mathrm{Fe}_{3} \mathrm{O}_{4}$ nanoparticles & 7.00 & Drinking water & [98] \\
\hline 40 & $\mathrm{CeO}_{2}-\mathrm{CNT}$ & 7.00 & Aqueous solution & [99] \\
\hline 41 & Zirconium oxide nanoparticles & 7.00 & Drinking water & [94] \\
\hline 42 & Fex $(\mathrm{OH}) \mathrm{y}$-Montmorillonite & 8.00 & Distill Water & [86] \\
\hline
\end{tabular}

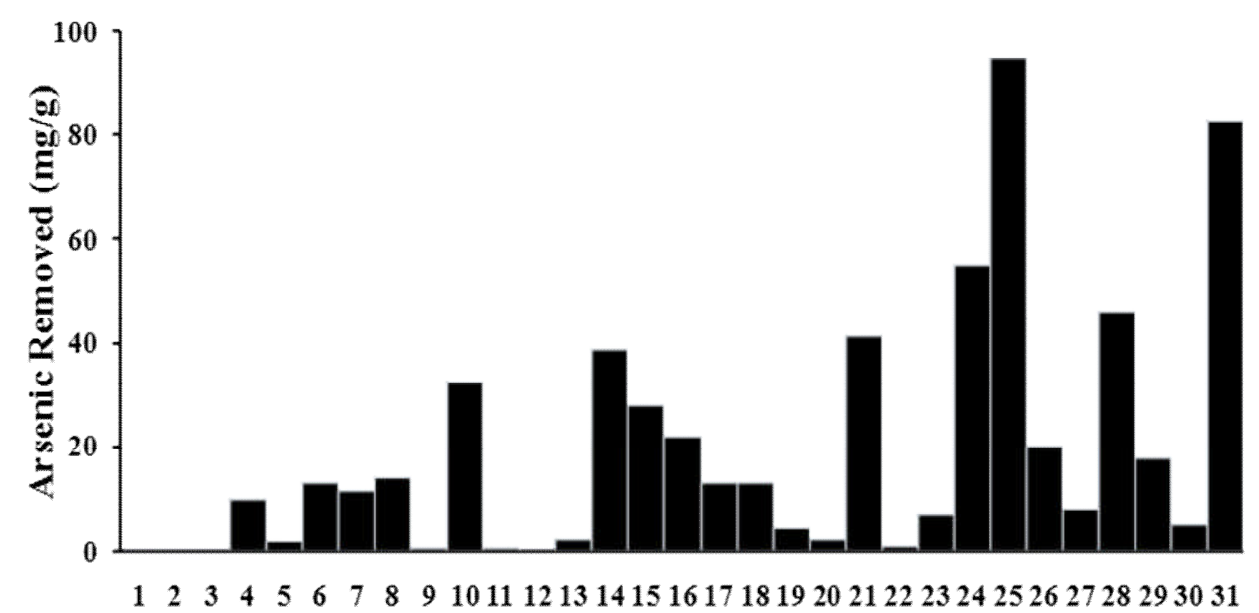

Adsorbant Type

Figure 2. Adsorption capacity of different adsorbents reported for arsenic (III) 
Table 3. Comparative evaluation among different adsorbents for Arsenic (III).

\begin{tabular}{|c|c|c|c|c|}
\hline Sr. No & Adsorbents & pH & Type of water & References \\
\hline 1 & Rice husk & 8.00 & Groundwater & {$[21,[72], 142]$} \\
\hline 2 & cellulose sponge & 4.5 & Tap water & [127] \\
\hline 3 & Rice Polish & 7.00 & Aqueous solution & {$[21]$} \\
\hline 4 & Oyster shell & 6.50 & Groundwater & [127] \\
\hline 5 & Copper-impregnated coconut husk carbon & 6.50 & Drinking Water & [129] \\
\hline 6 & Sorghum biomass & 5.00 & Distill water & {$[76,77]$} \\
\hline 7 & Modified chicken feathers & 4.00 & Tap water & [131] \\
\hline 8 & Allyl alcohol-treated chicken feathers & 7.00 & Synthetic water & {$[78]$} \\
\hline 9 & Natural siderite & 7.31 & Tap water & {$[80]$} \\
\hline 10 & Activated red mud & 7.25 & Distill water & {$[81]$} \\
\hline 11 & Bamboo charcoal & $4.00-5.00$ & Aqueous solution & {$[82]$} \\
\hline 12 & Granular titanium dioxide & 7.00 & Ground water & {$[83]$} \\
\hline 13 & Iron oxide-coated cement & 7,00 & Distill water & [24] \\
\hline 12 & Iron oxide-coated sand & 7.50 & Distill water & [23] \\
\hline 15 & Iron-modified activated carbon & 7.60 & Distill water & [85] \\
\hline 16 & Fex $(\mathrm{OH}) \mathrm{y}$-Montmorillonite & 6.00 & Distill water & [86] \\
\hline 17 & Ti xHy-Montmorillonite & 6.00 & Distill water & {$[86]$} \\
\hline 18 & Chitosan resin & 6.00 & Distill water & [86] \\
\hline 19 & Cerium-loaded cation exchange resin & $5.00-6.00$ & Waste water & {$[90]$} \\
\hline 20 & Granular titanium dioxide $\left(\mathrm{TiO}_{2}\right)$ & 7.50 & Ground water & {$[83]$} \\
\hline 21 & Activated alumina & 7.50 & Drinking water & [132] \\
\hline 22 & Pillared Clays and Iron Oxides & 10.00 & Drinking water & {$[86]$} \\
\hline 23 & Magnetite & 7.00 & Distill water & [181] \\
\hline 24 & Al nanocluster & $5.00-6.00$ & Ground water & [161] \\
\hline 25 & Iron modified bamboo & $4.00-5.00$ & Aqueous solution & [189] \\
\hline 26 & Lepidocrocites & 7.00 & Aqueous solution & {$[82]$} \\
\hline 27 & $\alpha-\mathrm{Fe}_{2} \mathrm{O}_{3}$ nanoparticles & 7.00 & Tap water & [92] \\
\hline 28 & $\mathrm{Fe}_{2} \mathrm{O}_{3}$ nanoparticles & 6.00 & Drinking water & [95] \\
\hline 29 & Magnetite nanoparticles & 6.50 & Aqueous solution & [96] \\
\hline 30 & $\mathrm{Fe}_{3} \mathrm{O}_{4}$ nanoparticles & 7.00 & Drinking water & [97] \\
\hline 31 & Ceria nanoparticles & - & Drinking water & [98] \\
\hline
\end{tabular}

Advance materials as adsorbents for arsenic and develop the molecular approach to recognize detoxification Molecular imprinting technology (MIT)

Molecular Imprinting Technology (MIT) the material to able the mimic natural recognition entities, such as biological and antibodies receptors [197-205]. It is an important and dynamic area of research, molecular imprinting is one of the has been considered as viable technique to design approach to produce materials with recognize the 
ability as compare to the natural system. MIT is a versatile and up growing technique to use in both chemical and biological molecules such as proteins and amino acids [206-208], nucleotide derivatives [209], drugs and food [210, 211], pollutants [212, 213], separation, purification sciences [212, 214219], catalysis [220], chemical sensors [221], drug delivery [222], biological antibodies and receptors system [206, 223, 224]. MIT is a simple technique, it is based on the complex between an analyte (template) and functional monomer in the presence of the cross- linking agent [225].

\section{Molecular imprinted polymers (MIPs)}

Imprinting polymers (IPs) are advanced state-of-art materials widely applied for the selective removal of molecule or ions characteristics to synthetic polymeric matrix. IPs are considered as an efficient system for the synthesis of promising materials are proficient to recognize targeted specie [226, 227]. In typical procedure, at the first step the copolymerization occur between cross-linking and functional monomers during the imprinting process of targeted specie. Initially the functional monomers form the complex with imprint specie and then polymerization ensue. The functional monomers are fixed in polymeric matrix by cross linker. Successful removal of the imprinted specie left binding sites polymer network that is identical in shape and size to the targeted analyte. The targeted template design is then expert into the polymer network that enables it to rebound to analyte with more specificity and selectivity [228, 229]. For metal ions, the molecular imprint can be interpreted as ionic imprint. The functional monomer is allowed to self-assemble around molded ions in the ionic printing process, and followed by cross-linking as desired. The selectivity of the analyte is obtained with respect to the cavity polymers where the complexing ligands are organized so as to match the target ion size, charge, co-ordination geometry and coordination number [230]. The process activates ionic sites that are specific and specially targeted chemicals. Typically, the imprinting system is easily processed by bulk printing, where the imprinted polymers are prepared in large quantities and then post-processing method such as grinding and sieving are required. However, the creation of binding sites within the polymer volume and the issue of impeding the diffusion of adsorbate during template rejection limit imprinted polymers prepared for practical applications [231]. Thus, over the years, in new imprinting methodologies surface imprinting is one of the important imprinting methods. The polymer imprinted on the surface not only has high selectivity, but also avoids problems with mass transfer and shows a significant promise for industrial applications [232-239]. So far there are some polymers imprinted with metal ions, including U(VI) [233], $\mathrm{Zr}(\mathrm{IV})$ [234]. The imprinted polymers $\mathrm{Ni}(\mathrm{II})$ [235], Fe (III) [236] and Cd(II) [237- 239] have been prepared by the surface imprinting technique causing the functional group to be immobilized on the surface of the silica gel for the selective separation of heavy metals from aqueous solution. However, few studies on the polymers printed with As (V) have been published. Recently, Chen et al., (2009) reported that 3-(2-aminoethylamino) propyltrimethoxysilane (AAPTS) has been modified As (V). The study shows that As (V) can be adsorbed by the modified mesoporous silica sorbet modified AAPTS by electrostatic effect because the compounds of As(III) are neutral in As the compounds of $\mathrm{As}(\mathrm{V})$ are negatively charged in the $\mathrm{pH}$ range 3-9 [240] whereas previous investigations show that AAPTS can be complexed with other heavy metal ions (such as $\mathrm{Cd}(\mathrm{II}), \mathrm{Cu}(\mathrm{II})$, $\mathrm{Ni}(\mathrm{II}), \mathrm{Pb}$ (II) and $\mathrm{Zn}(\mathrm{II})$ ) by coordination bond. [241].

\section{Conclusion}

It is concluded from the detailed review of literature that water contamination due to arsenic, it is a major problem worldwide. The adsorption of arsenic from aqueous solution plays an important role in controlling water pollution. There is great interest in the use of low-cost adsorbents. But review of the literature, many researchers has tried to exploit natural materials as low-cost adsorbents for arsenic removal. The arsenic adsorption capacity of a low cost adsorption technology offered vary depending on the characteristics of the individual adsorbent, arsenic, $\mathrm{pH}$, temperature and contact time. Adsorption technology, using natural materials and 
agricultural waste either in natural form or modified form is highly effective for the removal of arsenic from aqueous solutions and offers a cost-effective alternative compared to traditional chemical and physical remediation and cleaning techniques. The interest is increasing to develop the knowledge about the polymers Metrix and the interaction of the template is very challenging process it could be employed in different industries such waste water treatment, drinking water treatment, drug delivery, biosensors and recycling of the different rare metals.

\section{Acknowledgment}

This work was supported and funded by Pakistan Science foundation Pakistan under research grant number PSF/Res/S-SU/Chem (465).

\section{References}

1. A. IPCS, A. Compounds, International Programme on Chemical Safety (Environmental Health Criteria), Geneva, edn, 2 (2001) 224.

http://www.who.int/ipcs/publications/ehc/ehc 224/en/

2. A. A. Duker, E. Carranza and M. Hale, Environ. Int., 31 (2005) 631. https://doi.org/10.1016/j.envint.2004.10.020

3. T. Kazi, M. Arain, M.K. Jamali, N. Jalbani, H. Afridi, R. Sarfraz, J. Baig, A.Q. Shah, Ecotoxicol. Environ. Saf., 72 (2009) 301. https://doi.org/10.1016/j.ecoenv.2008.02.024

4. B. K. Mandal and K. T. Suzuki, Talanta, 58 (2002) 2015. https://doi.org/10.1016/S00399140(02)00268-0

5. T. G. Kazi, H. I. Afridi, N. Kazi, M. K. Jamali, M. B. Arain, N. Jalbani and G. A. Kandhro, Biol. Trace Elem. Res., 122 (2008) 1. https://doi.org/10.1007/s12011-007-8062-

6. $\stackrel{\mathrm{y}}{\mathrm{T}}$. G. Kazi, M .B. Arain, J. A. Baig, M. K. Jamali, H. I. Afridi, N. Jalbani, R. A. Sarfraz, A. Q. Shah and A. Niaz, Sci. Total Environ., 407 (2009) 1019.

http://doi.org/10.1016/j.scitotenv.2008.10.013

7. C. -H. Wang, J. -S. Jeng, P. -K. Yip, C. -L. Chen, L. -I. Hsu, Y. -M. Hsueh, H. -Y. Chiou and M. -M. Wu, J. Chen. Circulation, 105 (2002) 1804.

https://doi.org/10.1161/01.CIR.0000015862. 64816.B2

8. S. Tu, L. Ma, T. Luongo, Plant Soil, 258 (2004) https://doi.org/10.1023/B:PLSO.0000016499 .95722 .16

9. J. A. Baig, T. G. Kazi, A. Q. Shah, H. I. Afridi, G. A. Kandhro, S. Khan, N. F. Kolachi, S. K. Wadhwa, F. Shah and M. B. Arain, Food Chem. Toxicol, 49 (2011) 265. https://doi.org/10.1016/j.fct.2010.11.002

10. W. Ernst, Applied Geochem., 11 (1996) 163. https://doi.org/10.1016/08832927(95)00040-2

11. A. B. Mukherjee and P. Bhattacharya, Environ. Rev., 9 (2001) 189.

https://doi.org/10.1139/a01-007

12. S. Sarkar, A. Gupta, R. K. Biswas, A. K. Deb, J. E. Greenleaf and A. K. Sen Gupta, Water Res., 39 (2005) 2196.

https://doi.org/10.1016/j.watres.2005.04.002

13. M. Vithanage, B. B. Dabrowska, A. B. Mukherjee, A. Sandhi and P. Bhattacharya, Environ. Chem. Lett., 10 (2012) 217. https://doi.org/10.1007/s10311-011-0349-8

14. P. Bhattacharya, A.B. Mukherjee, G. Jacks, S. Nordqvist, Sci. Total Environ., 290 (2002) 165.

https://doi.org/10.1016/S0048$\underline{\text { 9697(01)01073-7 }}$

15. M. Rahman, M. Vahter, M. A. Wahed, N. Sohel, M. Yunus, P. K. Streatfield, S. El Arifeen, A. Bhuiya, K. Zaman and A. M. R. Chowdhury, J. Epidemiol. Community Health, 60 (2006) 242. https://doi.org/10.1136/jech.2005.040212

16. B. S. Gupta, S. Chatterjee, U. Rott, H. Kauffman, A. Bandopadhyay, W. DeGroot, N. Nag, A. Carbonell-Barrachina and S. Mukherjee, Environ. Pollut., 157 (2009) 3351.

https://doi.org/10.1016/j.envpol.2009.09.014

17. D. Van Halem, S. Bakker, G. Amy and J. Van Dijk, Drinking Water Eng. Sci., 2, 2009, (2009).

https://doi.org/10.5194/dwes-2-29-2009

18. C. H. Niu, B. Volesky and D. Cleiman, Water Res., 41 (2007) 2473. 
https://doi.org/10.1016/j.watres.2007.03.013

19. S. Chakravarty, V. Dureja, G. Bhattacharyya, S. Maity and S. Bhattacharjee, Water Res., 36 (2002) 625.

https://doi.org/10.1016/S00431354(01)00234-2

20. D. Ranjan, M. Talat and S. Hasan, J. Hazard. Mater., 166 (2009) 1050.

https://doi.org/10.1016/j.jhazmat.2008.12.013

21. S. Kundu, S. S. Kavalakatt, A. Pal, S. K. Ghosh, M. Mandal and T. Pal, Water Res., 38 (2004) 3780.

https://doi.org/10.1016/j.watres.2004.06.018

22. S. Kundu and A. Gupta, J. Colloid Interface Sci., 290 (2005) 52.

https://doi.org/10.1016/j.jcis.2005.04.006

23. S. Kundu and A. Gupta, Chem. Eng. J, 122 (2006) 93.

https://doi.org/10.1016/j.cej.2006.06.002

24. J. C. Ng, J. Wang and A. Shraim, Chemosphere, 52 (2003) 1353.

https://doi.org/10.1016/S0045-

6535(03)00470-3

25. C. Ng and R. Naidu, Environ. Geochem. Health, 31 (2009) 189.

https://doi.org/10.1007/s10653-008-9235-0

26. A. Shraim, X. Cui, S. Li, J. C. Ng, J. Wang, Y. Jin, Y. Liu, L. Guo, D. Li and S. Wang, Toxicol. Lett., 137 (2003) 35. https://doi.org/10.1016/S03784274(02)00379-X

27. J. C. Ng, Envir. Chem., 2 (2005) 146-160. https://doi.org/10.1071/EN05062

28. R. Singh, S. Singh, P. Parihar, V. P. Singh and S. M. Prasad, Ecotoxicol. Environ. Saf., 112 (2015) 247

https://doi.org/10.1016/j.ecoenv.2014.10.009

29. S. Murcott, Arsenic contamination in the world, IWA Publishing, 2012.

https://books.google.com.pk/books?hl=en\&lr $=\& \mathrm{id}=\mathrm{CHKNoVj0t} \mathrm{cC} \&$ oi=fnd\&pg

30. R. N. Ratnaike, Postgrad. Med. J., 79 (2003) 391.

https://doi.org/10.1136/pmj.79.933.391

31. D. Chakraborti, M. M. Rahman, B. Das, M. Murrill, S. Dey, S. C. Mukherjee, R. K. Dhar, B. K. Biswas, U. K. Chowdhury and S. Roy, Water Res., 44 (2010) 5789. https://doi.org/10.1016/j.watres.2010.06.051
32. H. Ahsan, Y. Chen, F. Parvez, L. Zablotska, M. Argos, I. Hussain, H. Momotaj, D. Levy, Z. Cheng and V. Slavkovich, Am. J. Epidemiol., 163 (2006) 1138. https://doi.org/10.1093/aje/kwj154

33. R. N. Ratnaike, Postgrad. Med. J., 79 (2003) 391.

https://doi.org/10.1136/pmj.79.933.391

34. J. Plant, D. Kinniburgh, P. Smedley, F. Fordyce, B. Klinck, Arsenic and selenium, Treatis. Geochem., 9 (2003) 612. doi 10.1016/B0-08-043751-6/09047

35. S. Lata and S. R. Samadder, J. Environ. Manage., 166 (2016) 387. https://doi.org/10.1016/j.jenvman.2015.10.03 $\underline{9}$

36. Y. Chen, F. Parvez, M. Gamble, T. Islam, A. Ahmed, M. Argos, J. H. Graziano and H. Ahsan, Toxicol. Appl. Pharmacol., 239 (2009) 184. https://doi.org/10.1016/j.taap.2009.01.010

37. D. Chakraborti, M. M. Rahman, B. Das, M. Murrill, S. Dey, S. C. Mukherjee, R. K. Dhar, B. K. Biswas, U. K. Chowdhury and S. Roy, Water Res., 44 (2010) 5789. https://doi.org/10.1016/j.watres.2010.06.051

38. D. Mohan and C. U. Pittman, J. Hazard. Mater., 142 (2007) 1. https://doi.org/10.1016/j.jhazmat.2007.01.00 $\underline{6}$

39. J. P. Maity, B. Nath, S. Kar, C. -Y. Chen, S. Banerjee, J. -S. Jean, M. -Y. Liu, J. A. Centeno, P. Bhattacharya and C. L. Chang, Environ. Geochem. Health, 34 (2012) 563. https://doi.org/10.1007/s10653-012-9458-y

40. D. G. Mazumder, U. Dasgupta, Kaohsiung J. Med. Sci., 27 (2011) 360 doi: 10.1016/j.kjms.2011.05.003

41. F. Hunter, A. Kip and J. Irvine, J. Pharm. Exp. Ther., 76 (1942) 207. doi: 10.1016/j.kjms.2011.05.003

42. J. Edmonds and K. Francesconi, Nature, 289 (1981) 602. https://doi.org/10.1038/289602a0

43. K. Edgell, USEPA method study 37 SW-846 method 3050 acid digestion of sediments, sludges, and soils, US Environmental Protection Agency, Environmental Monitoring Systems Laboratory, 1989. 
https://nepis.epa.gov/Exe/ZyNET.exe/2000T TR9.TXT?Zy

44. W. A. Lowenbach and J. S. Schlesinger, Arsenic: a preliminary materials balance, Environmental Protecton Agency, Office of Toxic Substances, 1979.

https://nepis.epa.gov/Exe/ZyNET.exe/9100A OMS.TXT?ZyActionD16/i425

45. H. Guo, D. Stüben and Z. Berner, Appl. Geochem., 22 (2007) 1039.

https://doi.org/10.1016/j.apgeochem.2007.01 .004

46. P. Smedley, H. Nicolli, D. Macdonald, A. Barros and J. Tullio, Appl. Geochem, 17 (2002) 259.

doi:10.1017/S0022029904000640

47. D. Kinniburgh and P. Smedley, vol 2. Final Report, British Geological Survey, in, BGS Technical Report No WC/00/19, 2001. http://www.ldeo.columbia.edu/ avangeen/pu blications/documents/Ahmed_Science_06.pd $\mathrm{f}$

48. S. S. Farías, V. A. Casa, C. Vázquez, L. Ferpozzi, G. N. Pucci and I. M. Cohen, Sci. Total Environ., 309 (2003) 187. doi:10.1016/S0048-9697(03)00056-1

49. J. Ahmad, B. Goldar and S. Misra, J. Environ. Manage., 74 (2005) 173. doi: 10.1002/clen.201200466

50. C. F. Harvey, C. H. Swartz, A. Badruzzaman, N. Keon-Blute, W. Yu, M. A. Ali, J. Jay, R. Beckie, V. Niedan and D. Brabander, Science, 298 (2002) 1602. https://www.ncbi.nlm.nih.gov/pmc/articles/P MC3184456/

51. T. Agusa, T. Kunito, R. Kubota, I. Monirith, S. Tanabe and T. Tana, Biomed. Res. Trace Elements, 13 (2002) 254.

https://www.terrapub.co.jp/onlineproceeding s/ec/06/pdf/PR616.pdf

52. Y. Xia, J. Liu, Toxicology, 198 (2004) 25. doi: $10.1186 / 2052$.

53. J. Guo, Y. Fujino, S. Kaneko, K. Wu, Y. Xia and T. Yoshimura, Springer, (2001) 137. doi:10.1016/j.chemosphere.2010.05.040

54. A. Sancha, Chile experience, Water Supply, (2000) 621.

http://dx.doi.org/10.1080/02508060.2010.50 $\underline{6275}$
55. D. K. Nordstrom, Science, 296 (2002) 2143. doi:10.1126/science.1072375.Source: PubMed

56. J. -P. Buchet and D. Lison, Food Chem. Toxicol., 38 (2000) S81. doi:10.1016/s0278-6915(99)00130-1

57. J. R. Parga, D. L. Cocke, J. L. Valenzuela, J. A. Gomes, M. Kesmez, G. Irwin, H. Moreno and M. Weir, J. Hazard. Mater., 124 (2005) 247. doi:10.1021/acs.estlett.6b00430

58. S. Sarkar, A. Gupta, R. K. Biswas, A. K. Deb, J. E. Greenleaf, A. K. Sen. Gupta, Water Res., 39 (2005) 2196. doi:10.1016/j.watres.2005.04.002. Source: PubMed

59. H. Kondo, Y. Ishiguro, K. Ohno, M. M. Toba and M. Takagi, Chem. research, 33 (1999)

1967. file:///C:/Users/Raqeeb\%20Raja/Downloads/ minerals-07-00099.pdf

60. M. E. Cebrian, A. Albores, M. Aguilar, E. Blakely, Hum. Toxicol., 2 (1983) 121. http://dx.doi.org/10.1177/096032718300200 $\underline{110}$

61. L. K. Ongley, M. A. Armienta, K. Heggeman, A. S. Lathrop, H. Mango, W. Miller and S. Pickelner, Geochem. Explor. Env. A, 1 (2001) 23. doi:10.1144/geochem.1.1.23

62. R. R. Shrestha, M. P. Shrestha, N. P. Upadhyay, R. Pradhan, R. Khadka, A. Maskey, M. Maharjan, S. Tuladhar, B. M. Dahal and K. Shrestha, J. Environ. Sci. Health A, 38 (2003) 185. doi:10.3390/w3010001

63. S. J. McLaren and N. D. Kim, Environ Pollut., 90 (1995) 67. doi: 10.1016/0269-7491(94)00092-R

64. J. Aggett, M. R. Kriegman, Water Res., 22 (1988) 407. doi: 10.1021/es051271i

65. G. A. Wasserman, X. Liu and F. Parvez, Neurotoxicology, 32 (2011) 450. doi:10.1289/ehp.1509974

66. M. Hamayun, T. Mahmood, A. Naeem, M. Muska, S. Din and M. Waseem, Chemosphere, 99 (2014) 207. doi: 10.1016/j.chemosphere.2013.10.075 . Source: PubMed 
67. S. Akhtar, Critical Rev. Food Sci. Nutr., 55 (2015) 219.

http://dx.doi.org/10.1080/10408398.2011.65 $\underline{0801}$

68. R. S. Burkel and R. C. Stoll, Ground Water Monit. Remediat., 19 (1999) 114. doi:10.1111/j.1745-6592.1999.tb00210.x

69. F. N. Robertson, Environ. Geochem. Hlth, 11 (1989) 171. doi: 10.1007/BF01758668

70. M. Berg, H. C. Tran, T. C. Nguyen, H. V. Pham, R. Schertenleib and W. Giger, Environ. Sci. Technol., 35 (2001) 2621. doi: 10.1021/es062798d

71. T. Agusa, T. Kunito, J. Fujihara, R. Kubota, T. B. Minh, P. T. K. Trang, H. Iwata, A. Subramanian, P. H. Viet and S. Tanabe, Environ. Pollut., 139 (2006) 95. doi: 10.2478/v10102-012-0007-4

72. H. S. Altundoğan, S. Altundoğan, F. TuÈmen and M. Bildik, Waste Manage., 20 (2000) 761.

https://doi.org/10.1016/S0956053X(00)00031-3

73. X. Liu, H. Ao, X. Xiong, J. Xiao and J. Liu, Water Air Soil Pollut., 223 (2012) 1033. https://doi.org/10.1007/s11270-011-0921-7

74. S. Bang, M. Patel, L. Lippincott and X. Meng, Chemosphere, 60 (2005) 389. https://doi.org/10.1016/j.chemosphere.2004.1 2.008

75. K. Wu, R. Liu, H. Liu, X. Zhao and J. Qu, Environ. Eng. Sci., 28 (2011) 643. https://doi.org/10.1089/ees.2010.0307

76. W. Chen, R. Parette, J. Zou, F. S. Cannon and B. A. Dempsey, Water Res., 41 (2007) 1851.

https://doi.org/10.1016/j.watres.2007.01.052

77. V. Lenoble, O. Bouras, V. Deluchat, B. Serpaud and J. -C. Bollinger, J. Colloid. Interf. Sci., 255 (2002) 52.

https://doi.org/10.1006/jcis.2002.8646

78. K. Sasaki, H. Nakano, W. Wilopo, Y. Miura and T. Hirajima, Colloids Surf. A, 347 (2009) 8. https://doi.org/10.1016/j.colsurfa.2008.10.03 $\underline{3}$

79. D. Mohapatra, D. Mishra, G. R. Chaudhury and R. P. Das, Korean J. Chem. Eng., 24 (2007) 426.
https://doi.org/10.1007/s11814-007-0073-Z

80. P. Bhakat, A. Gupta, S. Ayoob and S. Kundu, Physicochem. Eng. Asp., 281 (2006) 237.

https://doi.org/10.1016/j.colsurfa.2006.02.04 5

81. H. Zongliang, T. Senlin and N. Ping, J. Rare Earths, 30 (2012) 563.

https://doi.org/10.1016/S10020721(12)60092-1

82. J. Mendoza-Barrón, A. Jacobo-Azuara, R. Leyva-Ramos, M. S. Berber-Mendoza, R. M. Guerrero-Coronado, L. Fuentes-Rubio and J. M. Martínez-Rosales, Adsorption, 17 (2011) 489.

https://doi.org/10.1007/s10450-010-9307-1

83. J. L. Mathieu, Design strategies and preliminary prototype for a low-cost arsenic removal system for rural Bangladesh, Lawrence Berkeley National Laboratory, (2010).

84. P. Bhakat, A. Gupta, S. Ayoob and S. Kundu, A: Physicochem. Eng. Asp., 281 (2006) 237.

https://doi.org/10.1016/j.colsurfa.2006.02.04 $\underline{5}$

85. S. -H. Lee, K. -W. Kim, B. -T. Lee, S. Bang, H. Kim, H. Kang and A. Jang, Int. J. Environ. Res. Public Health, 12 (2015) 13523.

https://doi.org/10.3390/ijerph121013523

86. C. Lu and C. Liu, J. Chem. Technol. Biot., 81 (2006) 1932.

https://doi.org/10.1002/jctb.1626

87. S. Luther, N. Borgfeld, J. Kim and J. Parsons, Microchem. J., 101 (2012) 30. https://doi.org/10.1016/j.microc.2011.10.001

88. P. Roy, M. Choudhury and M. Ali, Int. J., 4 (2013)

http://dx.doi.org/10.1590/1980-5373-mr2015-0667

89. L. Feng, M. Cao, X. Ma, Y. Zhu and C. Hu, J. Hazard. Mater., 217 (2012) 439. https://doi.org/10.1016/j.jhazmat.2012.03.07 $\underline{3}$

90. X. Peng, Z. Luan, J. Ding, Z. Di, Y. Li and B. Tian, Mater. Lett., 59 (2005) 399. https://doi.org/10.1016/j.matlet.2004.05.090

91. J. A. Mu-oz, A. Gonzalo and M. Valiente, Environ. Sci. Technol., 36 (2002) 3405. 
https://doi.org/10.1021/es020017c

92. A. Samad, M. Arifur Rahman and A. M. Shafiqul Alam, Pak. J. Anal. Environ. Chem., 11 (2010) 28.

93. G. Manju, C. Raji and T. Anirudhan, Water Res., 32 (1998) 3062.

https://doi.org/10.1016/S00431354(98)00068-2

94. M. A. Khosa, J. Wu and A. Ullah, Res. Adv., 3 (2013) 20800. https://doi.org/10.1039/c3ra43787f

95. T. S. Singh and K. K. Pant, Water Qual. Res. J. Can., 41 (2006) 147. http://dx.doi.org/10.1080/00288306.2010.50 $\underline{0320}$

96. G. Manju, C. Raji and T. Anirudhan, Water Res., 32 (1998) 3062.

www.mdpi.com/1660-4601/13/1/62/pdf

97. M. A. Khosa, J. Wu and A. Ullah, Res. Adv., 3 (2013) 20800.

pubs.rsc.org/en/content/articlehtml/2013/ra/c 3ra43787f

98. S. Ghorai and K. Pant, Sep. Purif. Technol., 42 (2005) 265.

https://bibliotecausatpdqt.files.wordpress.co $\mathrm{m} /$.../adsorptive-removal-of-fluoride.pdf

99. R. Sullivan, Preliminary air pollution survey of arsenic and its compounds, A literature review. US Department of Health, Education, and Welfare, APTD, (1969) 69. http://dx.doi.org/10.1080/10643389.2016.12 45551

100. V. K. Sharma and M. Sohn, Environ. Int., 35 (2009) 743.

https://doi.org/10.1016/j.envint.2009.01.005

101. J. H. Gulledge and J. T. O'Connor, J. Am. Water Works Assoc., 65 (1973) 548. doi:10.1016/j.jhazmat.2010.12.085

102. A. Kabata-Pendias, H. Pendias, $C R C$ press Boca Raton., (1984). doi: 10.1016/S0927-5215(06)09024-2

103. O. X. Leupin and S. J. Hug, Water Res., 39 (2005) 1729. https://doi.org/10.1016/j.watres.2005.02.012

104. P. Smedley and D. Kinniburgh, Appl. Geogochem., 17 (2002) 517.

https://doi.org/10.1016/S08832927(02)00018-5

105. S. R. Al-Abed, G. Jegadeesan, J. Purandare and D. Allen, Chemosphere, 66 (2007) 775. https://doi.org/10.1016/j.chemosphere.2006.0 7.045

106. H. K. Hansen, P. Nú-ez and R. Grandon, Miner. Eng., 19 (2006) 521.

https://doi.org/10.1016/j.mineng.2005.09.048

107. R. Y. Ning, Desalination, 143 (2002) 237. https://doi.org/10.1016/S00119164(02)00262-X

108. B. Robinson, N. Kim, M. Marchetti, C. Moni, L. Schroeter, C. van den Dijssel, G. Milne and B. Clothier, Environ. Exp. Bot., 58 (2006) 206.

https://doi.org/10.1016/j.envexpbot.2005.08. $\underline{004}$

109. H. Brammer and P. Ravenscroft, Environ. Int., 35 (2009) 647.

https://doi.org/10.1016/j.envint.2008.10.004

110. M. Pirilä, M. Martikainen, K. Ainassaari, T. Kuokkanen and R. L. Keiski, J. Colloid. Interf. Sci., 353 (2011) 257. https://doi.org/10.1016/j.jcis.2010.09.020

111. A. Goswami, P. Raul and M. Purkait, Chem. Eng. Res. De.s, 90 (2012) 1387. https://doi.org/10.1016/j.cherd.2011.12.006

112. K. Banerjee, G. L. Amy, M. Prevost, S. Nour, M. Jekel, P. M. Gallagher and C. D. Blumenschein, Water Res., 42 (2008) 3371. https://doi.org/10.1016/j.watres.2008.04.019

113. P. Chutia, S. Kato, T. Kojima, S. Satokawa, J. Hazard. Mater., 162 (2009) 440. https://doi.org/10.1016/j.jhazmat.2008.05.06 $\underline{1}$

114. A. Goswami, P. Raul, M. Purkait, Chem. Eng. Res. Des., 90 (2012) 1387.

https://doi.org/10.1016/j.cherd.2011.12.006

115. B. Daus, R. Wennrich and H. Weiss, Water Res., 38 (2004) 2948. https://doi.org/10.1016/j.watres.2004.04.003

116. D. Li, C. Du, Y. Lin and M. Wu, 88 (2001) 522.

http://exp-oncology.com.ua/wp/wpcontent/uploads/magazine/235.pdf?upload=

117. N. Deedar and I. Aslam, J. Environ. Sci., 21 (2009) 402. https://doi.org/10.1016/S10010742(08)62283-4

118. K. Hristovski, A. Baumgardner and P. Westerhoff, J. Hazard. Mat., 147 (2007) 265. https://doi.org/10.1016/j.jhazmat.2007.01.01 $\underline{7}$ 
119. C. A. Martinson and K. Reddy, J. Colloid. Interf. Sci., 336 (2009) 406.

https://doi.org/10.1016/j.jcis.2009.04.075

120. K. D. Hristovski, P. K. Westerhoff, T. Möller and P. Sylvester, Chem. Eng. J., 146 (2009) 237.

https://doi.org/10.1016/j.cej.2008.05.040

121. A. Basu, S. Mitra, J. Chung, D. G. Mazumder, N. Ghosh, D. Kalman, O. S. Von Ehrenstein, C. Steinmaus, J. Liaw and A. H. Smith, Creatinine, Environ. Health. Persp., 119 (2011) 1308. https://doi.org/10.1289/ehp.1003393

122. C. A. Martinson and K. Reddy, J. Colloid. Interf. Sci., 336 (2009) 406.

https://doi.org/10.1016/j.jcis.2009.04.075

123. D. Pokhrel and T. Viraraghavan, Chem. Eng. J., 140 (2008) 165. https://doi.org/10.1016/j.cej.2007.09.038

124. H. Seki, A. Suzuki and H. Maruyama, J. Colloid. Interf. Sci., 281 (2005) 261. https://doi.org/10.1016/j.jcis.2004.08.167

125. D. Ranjan, M. Talat and S. Hasan, J. Hazard. Mater., 166 (2009) 1050.

https://doi.org/10.1016/j.jhazmat.2008.12.01 $\underline{3}$

126. C. H. Niu, B. Volesky and D. Cleiman, Water Res., 41 (2007) 2473. https://doi.org/10.1016/j.watres.2007.03.013

127. M. X. Loukidou, K. A. Matis, A. I. Zouboulis and M. Liakopoulou-Kyriakidou, Water Res., 37 (2003) 4544. https://doi.org/10.1016/S00431354(03)00415-9

128. T. Anirudhan and M. R. Unnithan, Chemosphere, 66 (2007) 60. https://doi.org/10.1016/j.chemosphere.2006.0 $\underline{5.031}$

129. Y. Zhao, M. Huang, W. Wu and W. Jin, Desalination, 249 (2009) 1006. https://doi.org/10.1016/j.desal.2009.09.015

130. Y. -N. Chen, L. -Y. Chai and Y. -D. Shu, J. Hazard. Mater., 160 (2008) 168. https://doi.org/10.1016/j.jhazmat.2008.02.12 $\underline{0}$

131. C. -P. Chio, M. -C. Lin and C. -M. Liao, J. Hazard. Mater., 171 (2009) 859. https://doi.org/10.1016/j.jhazmat.2009.06.08 $\underline{6}$
132. M. Urik, P. Littera and M. Kolen, Int. J. Environ. Sci., 6 (2009) 451. https://doi.org/10.1007/BF03326084

133. A. M. Yusof and N. A. N. N. Malek, J. Hazard. Mater., 162 (2009) 1019. https://doi.org/10.1016/j.jhazmat.2008.05.13 $\underline{4}$

134. C. -S. Jeon, K. Baek, J. -K. Park, Y. -K. Oh, and S. -D. Lee, J. Hazard. Mater., 163 (2009) 804.

https://doi.org/10.1016/j.jhazmat.2008.07.05 2

135. P. Chutia, S. Kato, T. Kojima and S. Satokawa, J. Hazard. Mater., 162 (2009) 204.

https://doi.org/10.1016/j.jhazmat.2008.05.02 $\underline{4}$

136. M. I. Khaskheli, S. Q. Memon, A. N. Siyal and M. Khuhawar, Waste Biomass. Valori., 2 (2011) 423. https://doi.org/10.1007/s12649-011-9081-7

137. S. Thapa and M. R. Pokhrel, J. Nep. Chem., Soc., 30 (2013) 29. http://dx.doi.org/10.3126/jncs.v30i0.9332

138. M. N. Amin, S. Kaneco, T. Kitagawa, A. Begum, H. Katsumata, T. Suzuki and K. Ohta, Ind. Eng. Chem. Res., 45 (2006) 8105. https://doi.org/10.1021/ie060344j

139. Z. Asif, Z. Chen, Appl. Water Sci., (2015) 1. doi: 10.1007/s13201-015-0323-X

140. S. Kamsonlian, C. Balomajumder, S. Chand and S. Suresh, Afr. J. Environ. Sci. Technol., 5 (2011) 1.

https://www.ajol.info/index.php/ajest/article/ view/71899

141. P. Aikpokpodion, R. Ipinmoroti and S. Omotoso, J. Soil Nature, 4 (2010) 7. http://dx.doi.org/10.1080/00986445.2017.13 06698

142. K. L. Wasewar, M. Atif, B. Prasad and I. Mishra, Desalination, 244 (2009) 66. https://doi.org/10.1016/j.desal.2008.04.036

143. K. L. Wasewar, M. Atif, B. Prasad and I. M. Mishra, CLEAN-Soil, Air, Water, 36 (2008) 320. https://doi.org/10.1002/clen.200700139

144. K. L. Wasewar, Int. J. Res. Rev. Appl. Sci., 3 (2010) 303. doi:10.1002/clen.200700139 
145. B. Amarasinghe and R. Williams, Chem. Eng J., 132 (2007) 299. https://doi.org/10.1016/j.cej.2007.01.016

146. K. L. Wasewar, M. Atif, B. Prasad and I. Mishra, Desalination, 244 (2009) 66. https://doi.org/10.1016/j.desal.2008.04.036

147. S. Cay, A. Uyanık and A. Özaşık, Sep. Purif. Technol., 38 (2004) 273. https://doi.org/10.1016/j.seppur.2003.12.003

148. N. Ingole and A. Bhole, J. Water. Supply. Res. T., 52 (2003) 119.

http://aqua.iwaponline.com/content/52/2/119

149. N. Ingole and A. Bhole, J. Water. Supply. Res. T., 52 (2003) 119. http://doi.org/10.1016/j.arabjc.2014.03.002

150. P. Aikpokpodion, R. Ipinmoroti and $\mathrm{S}$. Omotoso, Am. Eurasian J. Toxicol. Sci., 2 (2010) 72 .

151. B. Amarasinghe and R. Williams, Chem. Eng. J., 132 (2007) 299. https://doi.org/10.1016/j.cej.2007.01.016

152. S. Cay, A. Uyanık and A. Özaşık, Sep. Purif. Technol., 38 (2004) 273. https://doi.org/10.1016/j.seppur.2003.12.003

153. A. H. Mahvi, D. Naghipour, F. Vaezi and S. Nazmara, (2005)

http://agris.fao.org/agrissearch/search.do?recordID $=$ AV20120161528

154. K. L. Wasewar, Int. J. Res. Rev. App. Sci., 3 (2010) 303.

http://s3.amazonaws.com/academia.edu.docu $\underline{\text { ments/33541922/tea waste adsorption }}$

155. K. L. Wasewar, M. Atif, B. Prasad and I. M. Mishra, CLEAN-Soil, Air, Water, 36 (2008) 320. https://doi.org/10.1002/clen.200700139

156. A. A. Kader, A. Aly and B. Girgis, INT. SUGAR. J., (1996).

http://agris.fao.org/agrissearch/search.do?recordID=GB9705776

157. Y. -N. Chen, L. -Y. Chai and Y. -D. Shu, J. Hazard. Mater., 160 (2008) 168. https://doi.org/10.1016/j.jhazmat.2008.02.12 $\underline{0}$

158. F. Pagnanelli, S. Mainelli, F. Vegliò and L. Toro, Chem. Eng. Sci., 58 (2003) 4709. https://doi.org/10.1016/j.ces.2003.08.001

159. M. Rahaman, A. Basu and M. Islam, Bioresource Technol., 99 (2008) 2815. https://doi.org/10.1016/j.biortech.2007.06.03 $\underline{8}$

160. C. H. Niu, B. Volesky and D. Cleiman, Water res., 41 (2007) 2473. https://doi.org/10.1016/j.watres.2007.03.013

161. S. Q. Memon, M. Bhanger and J. -U. -R. Memon, Proc. First Tech. Meeting Muslim Water Res. Coope., (2008) 104.

http://www.ukm.my/muwarec/ProceedingMu warec08/9-Saima-11nov08.pdf

162. M. Gavrilescu, Eng. Life Sci., 4 (2004) 219. https://doi.org/10.1002/elsc.200420026

163. B. Volesky and B. V. Sorbex, Inc. Quebec: McGill University, (2003). 316 p, in, ISBN 0-9732983-0, 2003

http://biosorption.mcgill.ca/publication/BVib s05.pdf.

164. H. K. Hansen, A. Ribeiro and E. Mateus, Miner. Eng, 19 (2006) 486.

https://doi.org/10.1016/j.mineng.2005.08.018

165. H. Seki, A. Suzuki and H. Maruyama, J. Colloid. Interf. Sci., 281 (2005) 261. https://doi.org/10.1016/j.jcis.2004.08.167

166. H. Niu and B. Volesky, Hydrometallurgy, 71 (2003) 209.

https://doi.org/10.1016/S0304386X $(03) 00158-0$

167. C. H. Niu, B. Volesky and D. Cleiman, Water Res., 41 (2007) 2473. https://doi.org/10.1016/j.watres.2007.03.013

168. R. Leyva-Ramos, J. Moreno-Piraján, Ediciones Uniandes, Facultad de Ciencias, Departamento de Química, (2007) 155. doi: $10.1007 / \mathrm{s} 10450-010-9313-3$

169. P. Chutia, S. Kato, T. Kojima and S. Satokawa, J. Colloid. Interf. Sci., 162 (2009) 204.

https://doi.org/10.1016/j.jhazmat.2008.05.02 $\underline{4}$

170. R. Bowman, E. Sultivan, Z. Li and C. Colella, F. De freed Editore, Naples, (2000). https://link.springer.com/chapter/10.1007/0306-46928-6_8

171. G. M. Haggerty and R. S. Bowman, Environ. Sci. Technol., 28 (1994) 452. https://doi.org/10.1021/es00052a017

172. Z. Li, Langmuir, 15 (1999) 6438. https://doi.org/10.1021/la981535x

173. M. B. Baskan and A. Pala, Desalination, 281 (2011) 396. 
174. R. Leyva-Ramos, A. Jacobo-Azuara, P. Diaz-Flores, R. Guerrero-Coronado, J. Mendoza-Barron and M. Berber-Mendoza, Colloids Surf. A. Physicochem. Eng. Asp, 330 (2008) 35.

https://doi.org/10.1016/j.colsurfa.2008.07.02 $\underline{5}$

175. M. Majdan, S. Pikus, Z. Rzączyńska, M. Iwan, O. Maryuk, R. Kwiatkowski and $\mathrm{H}$. Skrzypek, J. Mol. Struct., 791 (2006) 53. https://doi.org/10.1016/j.molstruc.2005.12.04 3

176. P. Misaelides, V. Nikashina, A. Godelitsas, P. Gembitskii and E. Kats, J. Radioanal. Nucl. Ch., 227 (1998) 183.

https://doi.org/10.1007/BF02386458

177. S. Dixit and J. G. Hering, Environ. Sci. Technol., 37 (2003) 4182. https://doi.org/10.1021/es030309t

178. K. Ohe, T. Oshima and Y. Baba, Environ. Geochem. Hlth., 32 (2010) 283. https://doi.org/10.1007/s10653-010-9298-6

179. J. Parsons, M. Lopez, J. Peralta-Videa and J. Gardea-Torresdey, Microchem. J., 91 (2009) 100. https://doi.org/10.1016/j.microc.2008.08.012

180. K. Ohe, T. Oshima and Y. Baba, Environ. Geochem. Hlth., 32 (2010) 283. https://doi.org/10.1007/s10653-010-9298-6

181. U. Beker, L. Cumbal, D. Duranoglu, I. Kucuk and A. K. Sengupta, Environ. Geochem. Hlth., 32 (2010) 291. https://doi.org/10.1007/s10653-010-9301-2

182. Y. Mu, H. -Q. Yu, J. -C. Zheng, S .-J. Zhang and G. -P. Sheng, Chemosphere, 54 (2004) 789.

https://doi.org/10.1016/j.chemosphere.2003.1 $\underline{0.023}$

183. H. -H. Cho and J. -W. Park, Chemosphere, 64 (2006) 1047.

https://doi.org/10.1016/j.chemosphere.2005.1 2.062

184. Y. -T. Lin, C. -H. Weng and F. -Y. Chen, Sep. Purif. Technol., 64 (2008) 26. https://doi.org/10.1016/j.seppur.2008.08.012

185. I. Kouznetsova, P. Bayer, M. Ebert and M. Finkel, J. Contam. Hydrol., 90 (2007) 58. https://doi.org/10.1016/j.jconhyd.2006.09.01 $\underline{4}$
186. M. K. Ghosh, G. E. J. Poinern, T. B. Issa and P. Singh, Korean. J. Chem. Eng., 29 (2012) 95.

https://doi.org/10.1007/s11814-011-0137-y

187. M. Tadic, N. Citakovic, M. Panjan, B. Stanojevic, D. Markovic, Đ. Jovanovic and V. Spasojevic, J. Alloy Compd., 543 (2012) 118.

https://doi.org/10.1016/j.jallcom.2012.07.047

188. W. Tang, Q. Li, C. Li, S. Gao and J. K. Shang, J. Nanopart. Res., 13 (2011) 2641. https://doi.org/10.1007/s11051-010-0157-2

189. K. Ohe, Y. Tagai, S. Nakamura, T. Oshima and Y. Baba, J. Chem. Eng. Jpn., 38 (2005) 671-676.

https://doi.org/10.1252/jcej.38.671

190. J. Mayo, C. Yavuz, S. Yean, L. Cong, H. Shipley, W. Yu, J. Falkner, A. Kan, M. Tomson and V. Colvin, Sci. Tech. Adv. Mater., 8 (2007) 71. https://doi.org/10.1016/j.stam.2006.10.005

191. S. Dixit and J. G. Hering, Environ. Sci. Technol., 37 (2003) 4182. https://doi.org/10.1021/es030309t

192. J. Wang, Y. Wu and Y. Zhu, Mater. Chem. Phys., 106 (2007) 1. https://doi.org/10.1016/j.matchemphys.2007. $\underline{04.061}$

193. M. Auffan, J. Rose, J. -Y. Bottero, G. V. Lowry, J. -P. Jolivet and M. R. Wiesner, Nat. Nanotechnol., 4 (2009) 634. https://doi.org/10.1038/nnano.2009.242

194. J. Mertens, Rev. Environ. Sci. Bio., 10 (2011) 111. https://doi.org/10.1007/s11157-011-9239-6

195. G. Wulff, Angew. Chem. Int. Ed. (English), Angew. Chem, 34 (1995) 1812. https://doi.org/10.1002/anie.199518121

196. N. Masque, R. Marce and F. Borrull, Trends Anal. Chem. TrAC,, 20 (2001) 477. https://doi.org/10.1016/S01659936(01)00062-0

197. T. Takagishi and I. M. Klotz, Biopolymers, 11 (1972) 483. https://doi.org/10.1002/bip.1972.360110213

198. G. Wuff and A. Sarhan, J. Angew. Chem. Int. Ed, 11 (1972) 341. doi: 10.1002/jmr.2627.

199. K. Mosbach and O. Ramström, Nat Biotechnol., 14 (1996) 163. 
https://doi.org/10.1038/nbt0296-163

200. M. J. Whitcombe, C. Alexander and E. N. Vulfson, Trends. Food Sci. Tech., 8 (1997) 140.

https://doi.org/10.1016/S09242244(97)01024-8

201. S. Yan, Y. Fang and Z. Gao, Biosens. Bioelectro., 22 (2007) 1087.

https://doi.org/10.1016/j.bios.2006.03.007

202. C. Alexander, H. S. Andersson, L. I. Andersson, R. J. Ansell, N. Kirsch, I. A. Nicholls, J. O'Mahony and M. J. Whitcombe, J. Mol. Recognit., 19 (2006) 106. https://doi.org/10.1002/jmr.760

203. L. Ye and K. Mosbach, Chem. Mater., 20 (2008) 859.

https://doi.org/10.1021/cm703190w

204. E. V. Piletska, A. R. Guerreiro, M. J. Whitcombe and S. A. Piletsky, Macromolecules, 42 (2009) 4921. https://doi.org/10.1021/ma900432z

205. A. Poma, A. P. Turner and S. A. Piletsky, Trends in Biotechnol., 28 (2010) 629. https://doi.org/10.1016/j.tibtech.2010.08.006

206. A. Bossi, F. Bonini, A. Turner and S. Piletsky, Biosens. Bioelectron., 22 (2007) 1131.

https://doi.org/10.1016/j.bios.2006.06.023

207. I. Morelli, V. Chiono, G. Vozzi, G. Ciardelli, D. Silvestri and P. Giusti, Sens. Actuator. BChem., 150 (2010) 394. https://doi.org/10.1016/j.snb.2010.06.046

208. S. Scorrano, L. Mergola, R. Del Sole and G. Vasapollo, Int. J. Mol. Sci., 12 (2011) 1735. https://doi.org/10.3390/ijms12031735

209. L. Longo and G. Vasapollo, Mini. Rev. Org. Chem., 5 (2008) 163.

https://doi.org/10.2174/15701930878516162 $\underline{0}$

210. V. Pichon, F. Anal. Chimi. Act., 622 (2008) 48.

https://doi.org/10.1016/j.aca.2008.05.057

211. F. G. Tamayo, J. L. Casillas and A. MartinEsteban, Anal. Bioanal. Chem., 381 (2005) 1234. https://doi.org/10.1007/s00216-005-3071-1

212. F. Puoci, G. Cirillo, M. Curcio, F. Iemma, U. Spizzirri and N. Picci, Analytic. Chim. Act., 593 (2007) 164. https://doi.org/10.1016/j.aca.2007.04.053
213. C. Baggiani, L. Anfossi and C. Giovannoli, Analytic. Chimi. Act., 591 (2007) 29. https://doi.org/10.1016/j.aca.2007.01.056

214. L. I. Andersson, J. Chromatogr. B: Biomed. Sci. Appl., 745 (2000) 3. https://doi.org/10.1016/S03784347(00)00135-3

215. B. Sellergren, J. Chromatogr. A, 906 (2001) 227.

https://doi.org/10.1016/S00219673(00)00929-8

216. S. Wei and B. Mizaikoff, J. Sep. Sci., 30 (2007) 1794. https://doi.org/10.1002/jssc.200700166

217. F. Tamayo, E. Turiel and A. Martín-Esteban, J. Chromatogr. A, 1152 (2007) 32. https://doi.org/10.1016/j.chroma.2006.08.095

218. J. Haginaka, J. Chromatogr. B, 866 (2008) 3. https://doi.org/10.1016/j.jchromb.2007.07.01 $\underline{9}$

219. M. Lasáková and P. Jandera, J. Sep. Sci., 32 (2009) 799. https://doi.org/10.1002/jssc.200800684

220. S. A. Piletsky, N. W. Turner and P. Laitenberger, Med. Eng. Phys., 28 (2006) 971.

https://doi.org/10.1016/j.medengphy.2006.05 .004

221. W. Li and S. Li, Oligomers-Poly. Compost. Molec. Imprinting, (2007) 191. doi: 10.1007/12_2006_105.

222. F. Puoci, F. Iemma and N. Picci, Current Drug Deliv., 5 (2008) 85. https://doi.org/10.2174/15672010878395488 $\underline{8}$

223. L. Luigia and V. Giuseppe, Met. Based Drugs, 2008 (2007). doi:10.3390/s17040675

224. Y. Ge and A. P. Turner, Chem. A Euro. J., 15 (2009) 8100. https://doi.org/10.1002/chem.200802401

225. O. Ramström and K. Mosbach, Curr. Opin. Chem. Biol., 3 (1999) 759. https://doi.org/10.1016/S13675931(99)00037-X

226. K. Haupt, Peer reviewed: molecularly imprinted polymers: the next generation, in, ACS Publications, 2003. doi: $10.1021 / \mathrm{ac} 031385 \mathrm{~h}$ 
227. K. Haupt and K. Mosbach, Chem. Rev., 100 (2000) 2495.

https://doi.org/10.1021/cr990099w

228. T.P. Rao, R. Kala and S. Daniel, Analytic. Chimi. Act., 578 (2006) 105. https://doi.org/10.1016/j.aca.2006.06.065

229. C. J. Tan and Y. W. Tong, Anal. Bioanal. Chem., 389 (2007) 369. https://doi.org/10.1007/s00216-007-1362-4

230. M. Shamsipur, J. Fasihi and K. Ashtari, Anal. Chem.., 79 (2007) 7116. https://doi.org/10.1021/ac070968e

231. X. Chang, X. Wang, N. Jiang, Q. He, Y. Zhai, X. Zhu and Z. Hu, Microchimica. Act., 162 (2008) 113. doi: 10.1007/s00604-007-0870-4

232. N. Jiang, X. Chang, H. Zheng, Q. He and Z. Hu, Analytic. Chim. Act., 577 (2006) 225. https://doi.org/10.1016/j.aca.2006.06.049

233. X. Chang, N. Jiang, H. Zheng, Q. He, Z. Hu, Y. Zhai and Y. Cui, Talanta, 71 (2007) 38. https://doi.org/10.1016/j.talanta.2006.03.012

234. E. S. Kunarti, Desalination, 251 (2010) 83. https://doi.org/10.1016/j.desal.2009.09.139

235. G. -Z. Fang, J. Tan and X. -P. Yan, Anal. Chem., 77 (2005) 1734. https://doi.org/10.1021/ac048570v

236. Y. -K. Lu and X. -P. Yan, Anal. Chem.., 76 (2004) 453.

https://doi.org/10.1021/ac0347718
237. D. Chen, C. Huang, M. He and B. Hu, J. Hazard. Mater., 164 (2009) 114. https://doi.org/10.1016/j.jhazmat.2008.09.02 $\underline{2}$

238. C. Alié, S. Lambert, B. Heinrichs, R. Pirard and J. -P. Pirard, Catalysts, (2001). doi:10.1023/A:1020799616387

239. L. Bois, A. Bonhommé, A. Ribes, B. Pais, G. Raffin and F. Tessier, A, Physicochem. Eng. Asp., 221 (2003) 221. https://doi.org/10.1016/S09277757(03)00138-9

240. J. Aguado, J. M. Arsuaga, A. Arencibia, M. Lindo and V. Gascón, J. Hazard. Mater., 163 (2009) 213.

https://doi.org/10.1016/j.jhazmat.2008.06.08 $\underline{0}$

241. R. Ebrahimi, A. Maleki, B. Shahmoradi, H. Daraei, A.H. Mahvi, A.H. Barati and A. Eslami, Desal. Water Treat., 51 (2013) 2306 https://doi.org/10.1080/19443994.2012.7346 $\underline{75}$

242. S. V. Jadhav, E. Bringas, G. D. Yadav, V. K. Rathod, I. Ortiz and K. V. Marathe, J. Environ. Manage., 162 (2015) 306. https://doi.org/10.1016/j.jenvman.2015.07.02 $\underline{0}$ 